Journal of Life Economics

Cilt / Volume 7, Sayı / Issue 1, 2020, pp. 17-28

E - ISSN: 2148-4139

URL: https://www.ratingacademy.com.tr/ojs/index.php/jlecon

DOİ: https://doi.org/10.15637/jlecon.7.002

Araştırma Makalesi/Research Article

\title{
THE INFLUENTIAL POWER AND THE IMPORTANCE OF MUSIC IN ADVERTISING AND MARKETING
}

\author{
Bajram ÇUPI * \& Shemsi MORINA ** \\ * Assist. Prof. Dr., University of Prizren Ukshin Hoti, \\ KOSOVA, e-mail: bajramcupi@yahoo.com \\ ORCID ID: https://orcid.org/0000-0003-3340-5496 \\ ** Assist. Prof. Dr., University of Prizren Ukshin Hoti, \\ KOSOVA, e-mail: shemsi.morina@uni-prizren.com \\ ORCID ID: https://orcid.org/0000-0003-2826-2654
}

Geliş Tarihi: 3 Ekim 2019; Kabul Tarihi: 22 Ocak 2020

Received: 3 October 2019; Accepted: 22 January 2020

\begin{abstract}
Music is related to the spiritual state of the ones who listen or create it, so it is a kind of reflection of the state of mind, humour and the human feelings. Music is powerful and has a multifaceted influence on everyday life. It, among other things, is also an important part of television advertising. The purpose of advertising is known to be for perusading costumer in product quality, but to achieve this effect, music should be well combined with the right advertisement.It is significant for consumers to understand the advertising message, where the link to an emotional level can lead directly to the purchase. So, the best commercials are those that have both major effects: information and emotional power. This study was conducted through site work, surveying some of the managers of the largest commercial companies in Peja and their customers as well. The purpose of the survey was to determine the importance of music in advertising and its impact on consumers.
\end{abstract}

Keywords: Music, commercials, information, emotional power

Jel Codes: M31 M37 ve Z11 


\section{INTRODUCTION}

The focus of the current study is on the advertising music and its impact on the promotion of different companies and products. The main focus of this study is only oriented to the advertisements that are part of the televisions broadcasting on the territory of Kosovo. Besides, it bringsto the readers the fact that almost all the commercials broadcasted on these visual media contain melodic lines in the background of their lyrics. For this reason, were analyzed the impressions of company managers and customers, namely the two directly related parties, on the degree and direction of the influence of advertising music.

Preliminary marketing knowledge suggests that marketing is not just a genuine academic discipline, it is primarily a management function, and as such anybody who intends to have this professional marketing skill ought tobe able to demonstrate them in order to apply his knowledge of "Real Life" marketing processes.

The marketing notion summarizes the business philosophy of the enterprise, institution or individual that characterizes the concentration, i.e., focus on the customer, expressed through the permanent and harmonious efforts of the entire enterprise in the process of meeting the needs and desires of the costumer as well as the achievement of the objectives of the enterprise. According to Elamzi (2007)There is only one fair concept for the mission of an enterprise: customer satisfaction. What the enterprise thinks to produce is not of primary importance especially not for its future and success. Crucial is what the consumer thinks to buy what it is to value that determines what your business is, what it is to produce and whether it will thrive.

The reason that makes newspaper publishers and magazines to strive for more interesting publications is to encourage readers to say, "This article was great." So if you try to advertise your product, never ask: "What makes our product that good?" Instead, ask the question: "What makes our product interesting to readers of that newspaper or magazine?(Hasani, 2006)

To conduct this study, we have been encouraged by some previous researcheson television commercials, which, although they do not belong to the artistic aspect of music, the role of music in the advertising effectiveness hasbeen completely denied. In fact, the melodic lines or music are not even mentioned.

\section{RESEARCH METHODOLOGY}

\subsection{Objectives of the Study}

The primary purpose of our study is to enlighten the influential power and importance of music in advertising and marketing viewed from different perspectives, in particular, emphasizing the psychological context of consumers.

\subsection{Methods}

Various methods were applied to conduct the current study.

Theoretical analysis method -Consulting the most up-to-date literature of national and international authors who have addressed the influential power of music in advertising and marketing, the current work theoretically reflected the authors' perspectives and the role and importance they have given to music and its impact on advertising and marketing, respectively in promoting them to consumers.

Comparison method -Through this method the researchers tried to compare advertising as well as non-music marketing, and based on the arguments raised we have been able to highlight the advantages that music has in advertising and marketing, and its irreplaceable and highly influential role on consumers, namely on successfuladvertising. 
Quantitative Method - This method was applied, since the questionnaire, namely the survey technique, was used as a data collection instrument.

\subsection{Sampling and Research Instrumentation}

The questionnaire was used to collect data that enabledanswering the research question. In this study, the scientific, pedagogical and statistical research methods and criteria were applied through a survey. The purpose of the survey was to establish the importance of music in advertising and its impact on consumers. The survey was conducted with several companies that used music in their advertising and consumers who purchased the products.

In order to have reliable data for the current work,the survey was conducted with managers in six trading companies in Peja and with consumers of the those companies. The total number of surveyed consumers is fifty and all were adults.

Furthermore, the surveys were designed in accordance with the two stakeholders whose experience brought out the reality of the extent of the influence of advertising music in assessing the quality of product and the service of the companies. Both the first survey to which the managers were subjected, as well as the second one, which was compiled with customers, consisted of five different questions. Answers to the survey questions in both cases had only the option of a closed answer. After the surveying process, the all data were analysed and presented graphically and converted to numeric percent values.

\subsection{Hypotheses}

Based on the the study issuesome hypotheses have been raised, where the percentage of veracitywas achieved upon completion of the study.

\section{Hypotheses raised:}

- Music in ads, according to managers, is not a negligible element for advertising effectiveness.

- Music in commercials, for consumers, is an influential element for their belief in the quality of the product or service.

- Music in commercials is a desirable element for the formation of the authority of trading companies

- Music is an accessible "catchy' element for consumers ear.

- The use of consumer-friendly music commercials is a factor that increases the sales of advertised products.

No matter how we feel, no matter who we are with, before the music all surrender. Music is the social act of communication between people, a gesture of friendship, which tells us that the human is better than we think. In many cultures, music is an important part of people's way of living, as it plays a key role in religious rituals, ritual ceremonies(i.e. Graduation and Marriage/Wedding ), social activities (i.e. dancing ) and cultural activities,starting from karaoke singing to a community or local choir. Therefore, all this makes us realize that music is special and influences in many aspects, so we make music part of the advertisements.As a result, it was raisedthe research question:

What impact will music have on consumers and howit influences the companies? 


\section{LITERATURE REVIEW}

\subsection{Influence of music on advertising and marketing}

Up to nowadays, advertising has only been studied from a linguistic point of view and somehow the role of the melodic line of music as an integral part of it has been overlooked. This is especially true for commercials broadcasted on television, as music is not even mentioned as an integral part. In advertising, music can serve as a general promotional purpose in one or more capacities. In this respect, Canadian researcher Huron (2013) defined six main effective ways for advertising music which include: entertainment, structure and continuity, memorization, language/lyrics, intent and the gaining of authority.

He also claimed that the music in the commercials was about integrated music, so he introduced a short 15-second music sequence into the electronic media commercials and thereby proved the success of its use in advertising.

Music in advertising affects the way viewers perceive the interior through different means and levels and can significantly influence the emotional response to television advertising.

Driven by this study and by completely ignoring music as an influential factor in advertising success we found it necessary to study the influence and role of music in advertising from the perspective of companies, on the one hand, and customers on the other. Moreover, Huron (2013) explains:

1. The entertainment aspect of music helps make advertising more appealing by adding aesthetic value to it. An advertisement that has high aesthetic value will be able to grab more public attention. From this point of view, music does not necessarily have to show any particular connection to a particular product or service in order to play an effective and useful function. The music functions more like a bridge between the viewer and the advertisement in this case.

2.Music supports the structure and continuity of an advertisment by mediating between separate images. Accompanying a television advertisement shows that the music either structure the story or tells the narrative itself. It can also create an antagonist and protagonist within this story by giving them typical figures: musical, harmonic or melodic. Moreover, music has the ability to emphasize dramatic moments within the revelation and therefore create structure and continuity.

3. Music serves to make a product more memorable for the viewer, so stay in the minds of the listeners. So in an advertisement the content of the ad continues along with the music. Easily recognizable or easily memorized music is put into television commercials to create a positive memory relationship and make sense to the viewer.

4. Word and song mixes give advertisers the opportunity for two logical appeals, the spoken and written language. Music can provide a message to consumers to understand it consciously.

5.Usingdifferent types of music genres in the advertising world helps advertisers attract the audience they think will be interested in their products. The idea that there is a specific group of people that an advertiser is trying to reach is called a target audience, and music is an important aspect of what attracts the target audience. Music can create a connection between the viewer and a product, so it is considered important for advertisers to select the right music for the target audience. 
6. Establishing authority for music advertising is the idea that using specific types of music can help make the product more credible. This is another way companies can persuade consumers to buy their products. Using a specific song that carries weight on the target audience the advertiser is trying to reach and strengthen the link between the product and the consumer.

\subsection{Advertisement and Marketing}

Marketing is an activity, set of institutions and processes for creating, communicating, distributing and exchanging offers that are of value to clients, partners and society at large.Advertising is an action that draws public attention to something. So, advertising is not just printed material, TV videos or any other online presentations on the Internet. But, advertising is an action that draws attention to a product or service.

Whereas,Kotler ( n.d.) defines Marketing as a social and management process, through which, individuals and groups gain what they need and want, through the creation, delivery, and exchange of valuable products with others. One of the main reasons to use music in your marketing is visibility.

Solo artists and bands have their fans, and those fans are clients. From small social campaigns to lifelong support, music marketing will increase your marketing visibility. Music in the Marketing field can be a unique way to get your business or service focused. Pairing business with a suitable artist can help spark interest in what you offer.

The music industry is huge and growing day by day. Social media has removed almost all barriers to entry, allowing anyone to become a successful artist. This process, which is used to take years of development, can happen almost overnight. This can work in favor of businesses as well. Imagine having a soft drink that uses the music of a famous Albanian artist in marketing video and they choose to drink the product in the video, then the video becomes viral and their song becomes a hit on the radio so they can go on tour at home and abroad, thus increasing the globalization of the product. This may sound unrealistic, but it may be more likely than we think. There are many reasons why businesses should consider using music, in short, music unites people, and this is part of the ultimate mission, where a music band and a brand are opening the door to success and wealth.

This research has been done to a relatively small sample of consumers and business owners, respectively managers, and the effect may not be general. But, based on the findings, at any rate, it can be seen that music has an impact on almost all walks of life whether social, health, etc., and also makes us realize that companies which in their advertising include music reach to bring the consumer as close as possible to the product, earning in this way to increase the revenue.

The most common ads are local ads that normally last no longer than a minute and longer programs, which usually last up to an hour, known as (whistleblowers), specifically as in our Top Shop ads. TVs often turn to old songs because their sounds are closest to each other, they are fun and very popular, but sometimes you just do not remember which song it is . You might have heard the song many times before, but the moment it appears on TV suddenly (in a short clip) remembering the song title can be a challenge. Therefore, this drives the consumer to delve deeper into the topic.

Finally, well-known songs are usually used on television commercials, where in most television ads can be found artists and song titles of the world famous artisits, where you can also find out whether or not you heard the song in the original version. 
- Examples:

Advertisment: Pepsi HD.

Song : : Wewill Rock You (Britney Spears, Beyonce, Pink\& Enrique Iglesias)

Is this the original version? No

Song: We will Rock you (Queen)Is this the original version? Yes

Advertisment: „Vita“-Milk

Song: Vita Vita (DonatQosja - NaimShaci)

Is this the original version? No

Song: DabaDaba (Nita \&Rina Krasniqi)

Is this the original version? Yes

\subsection{Types of advertising}

From ancient Egypt, advertising has served as a critical purpose in the business world, a purpose that continues to be used today only in a more advanced way. When it is said more advanced is meant using images and music or audio.

Advertising represents any public announcements transmitted with similar pay or reward for the purpose of self-promotion intended to promote the sale, purchase or lease of a product or service, to promote any ideas or matters, or to cause other effects desired by the advertiser or the broadcaster himself. The primary function of music advertising is to persuade people to buy something. Consequently understanding how advertising affects people is an exercise in understanding how persuasion techniques are used in advertising to make purchasing decisions. Persuading techniques can be rational, irrational, or a combination of both.

The rational technique is used for so-called informational advertising. Because information is used to help people make informed purchasing decisions, so they make comparisons to competing products and provide evidence-based arguments that make consumers make logical purchasing decisions and that with the help of music it is usually easier, i.e. relaxing music, entertaining or classical music, this technique of advertising makes it less boring and more attractive. The irrational technique is used in so-called transformative advertising or by experience. Unlike informational advertising, which is the product-centered advertising, transformative advertising is the user-centered advertising. It is more like fun, appealing, emotional, it is softer, richer and more enjoyable.

\section{Research Results}

\subsection{Findings from Managers Survey}

When asked, "Have you used music in your firm's commercials broadcasted on TV?", Four out of six respondents stated that their ads contained a melodic line, which is $66.7 \%$. 
Graph 1. Music in TV commercials

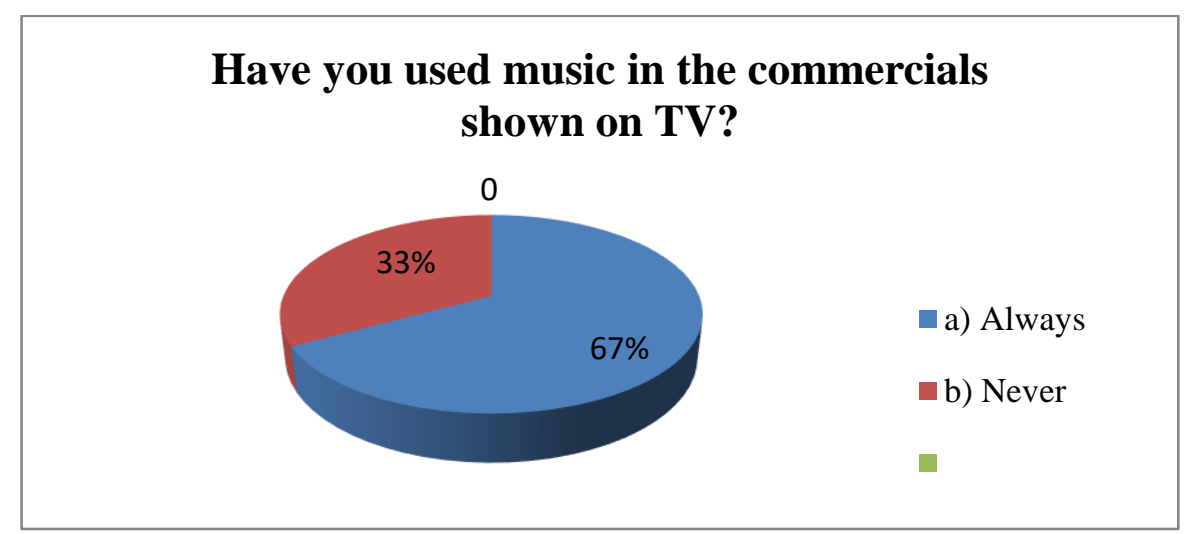

Source (authors 2020)

In the second question Have you used music advertising to advertise your company, or any other specific product?, all respondents, $100 \%$ answered that they used music in all advertisements, i.e., in product promotion ads and in those of company advertising.

Graph 2. Advertising your company or products through music

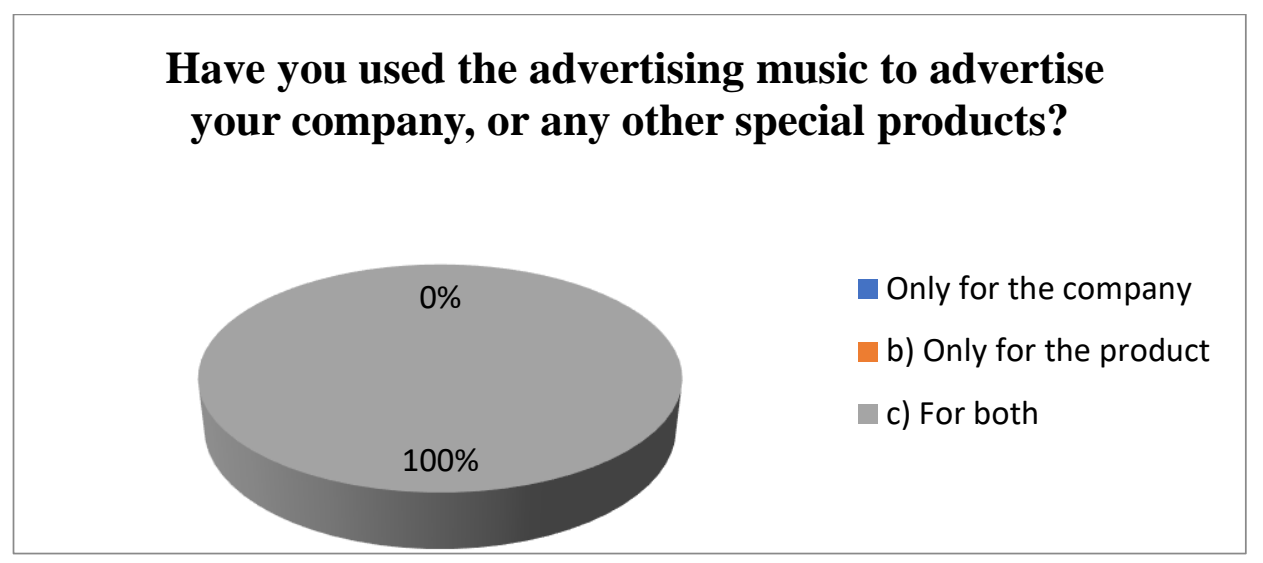

Source (authors 2020)

In the third question to the managers of companies through the questionnaire: Do you think advertising would have the same effect as with music, as without it?, In $67 \%$ of the answers there were statements that advertising with music is more effective.

Graph 3. The effect of music in advertising

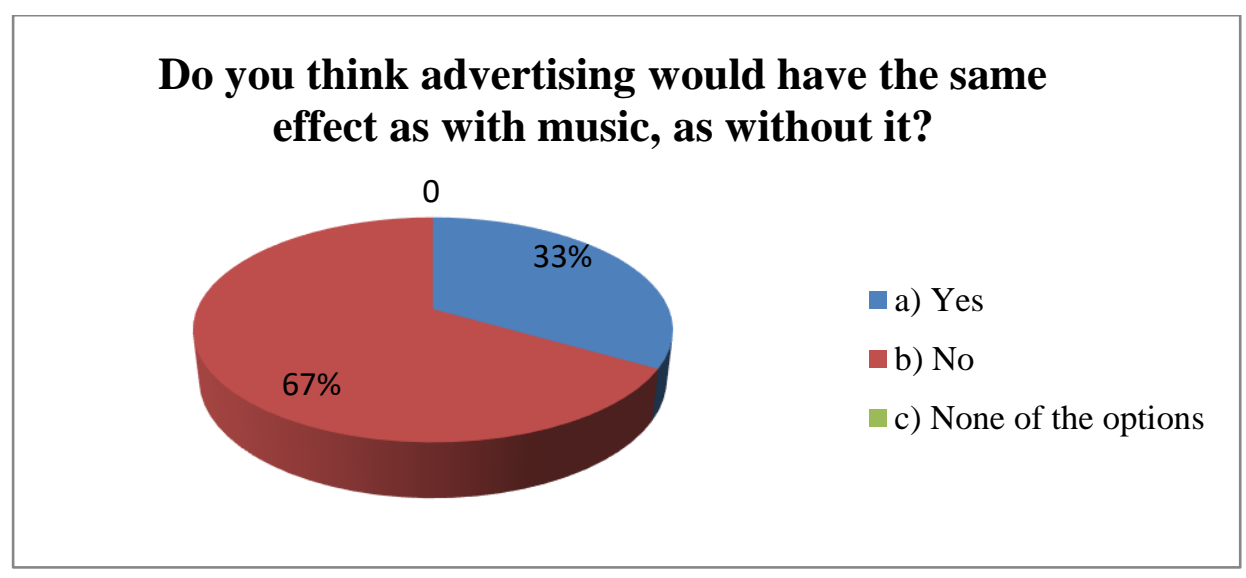

Source (authors 2020) 
To the fourth question: Since the use of music advertising has the sale been increased? Again the respondents answers were in favor of music as an influential element in the realization of their purpose.

Graph 4. The effect of music in sales

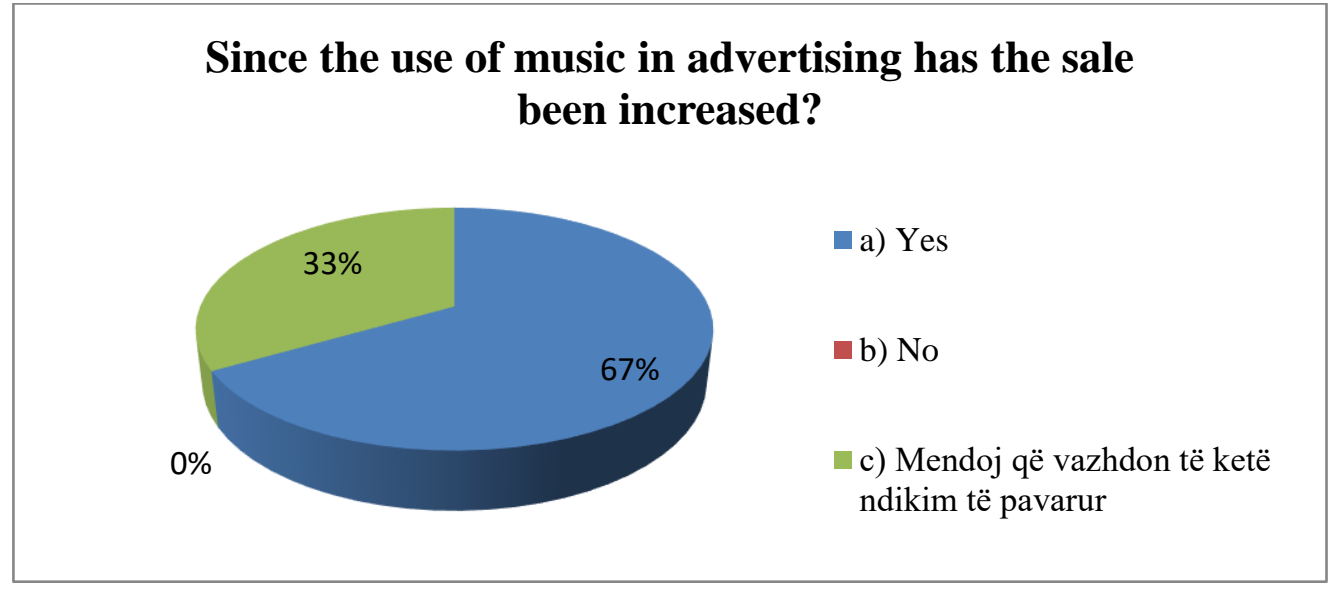

Source (authors 2020)

The question: Which ads are more successful? With closed options a) With words and music; b) Only with music and c) With words only, again, it turned out that in $67 \%$ of cases music is valued in parallel with language elements, however, when they work in harmony with one another.

Grap 5. Successful advertisements

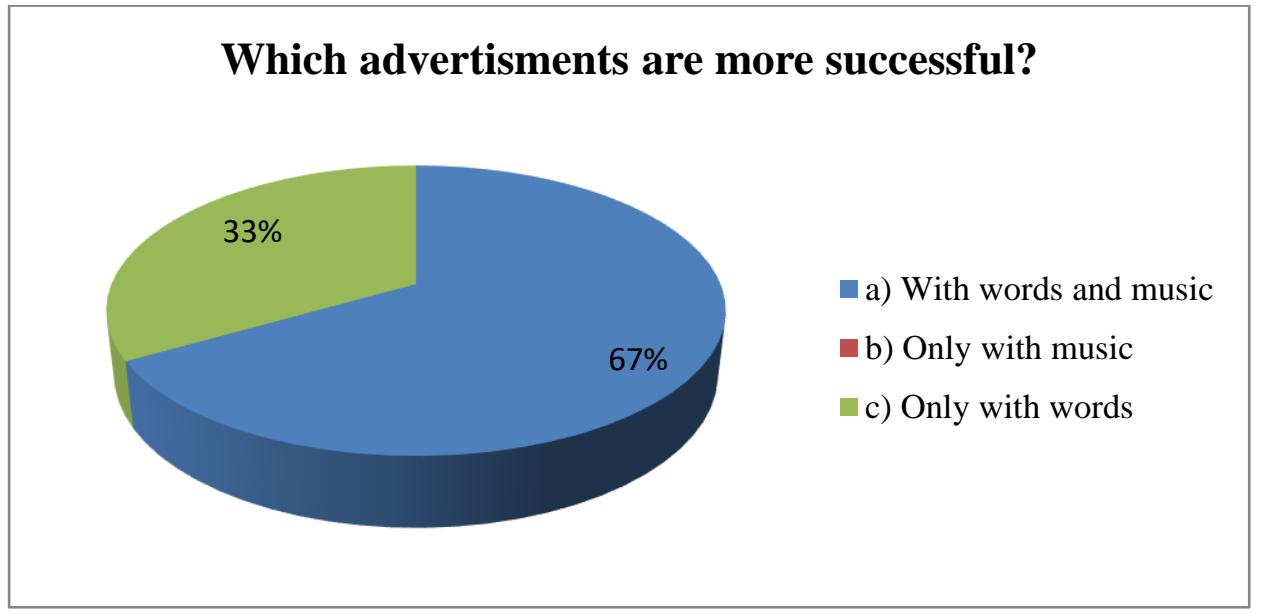

Source (authors 2020) 


\subsection{Findings from Customers Survey}

For customers were compiled these five questions.

Graph 6. Costumers interest in TV commercials

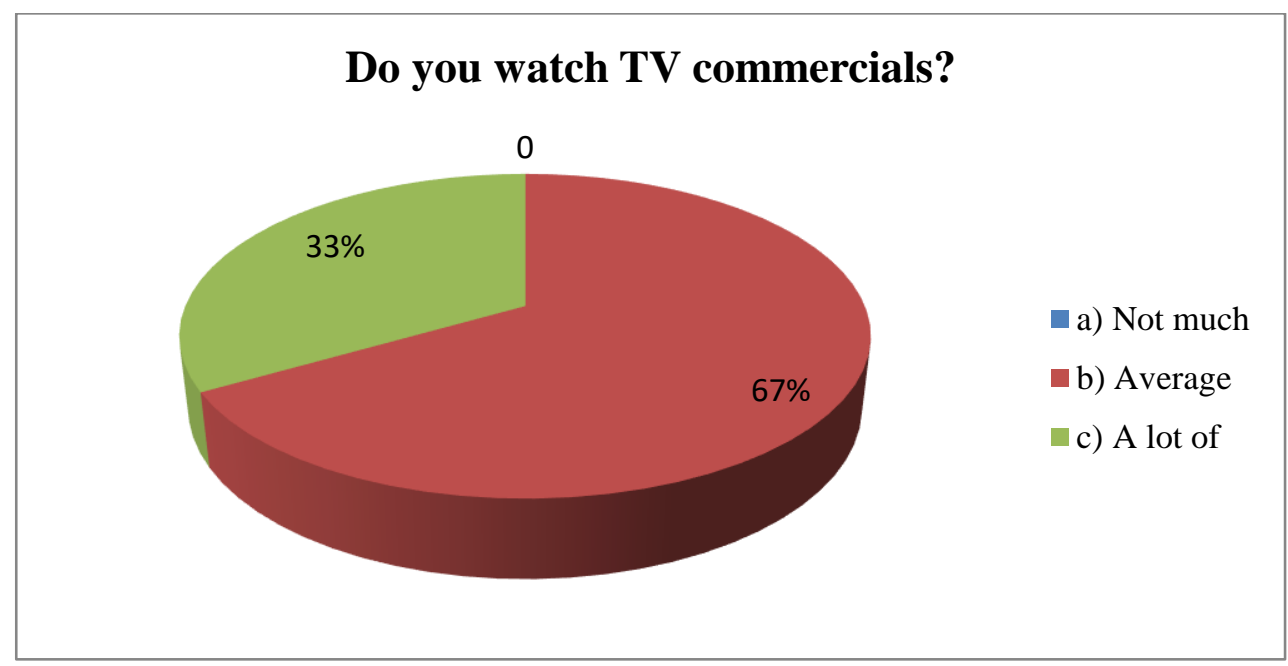

Source (authors 2020)

From the answers to the first question directed at customers it appears that they watch marketing on television on average of over $67 \%$ of cases. This result gives us the right to continue with their survey.

Graph 7. TV commercials that contain music

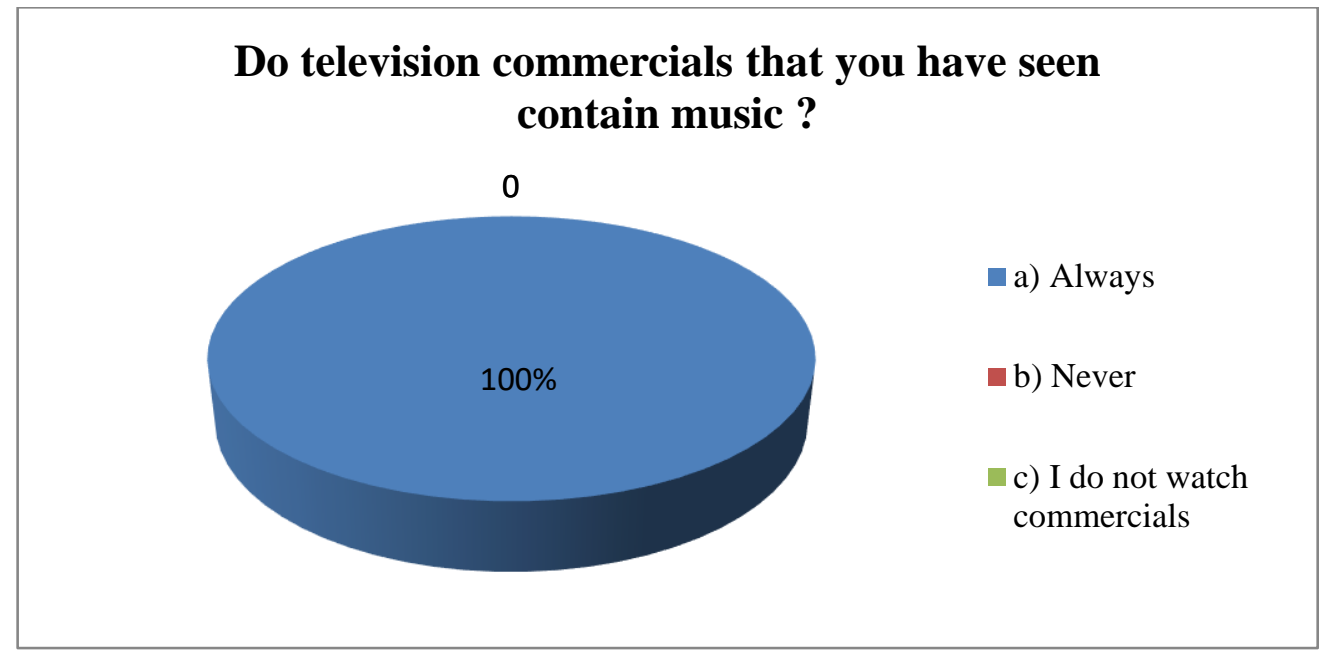

Source (authors 2020)

From the second question it turned out that the ear of viewers who are customers of certain companies catches the musical element within the ads in $100 \%$ of the cases. 
Graph 8. Using favourable music in advertising

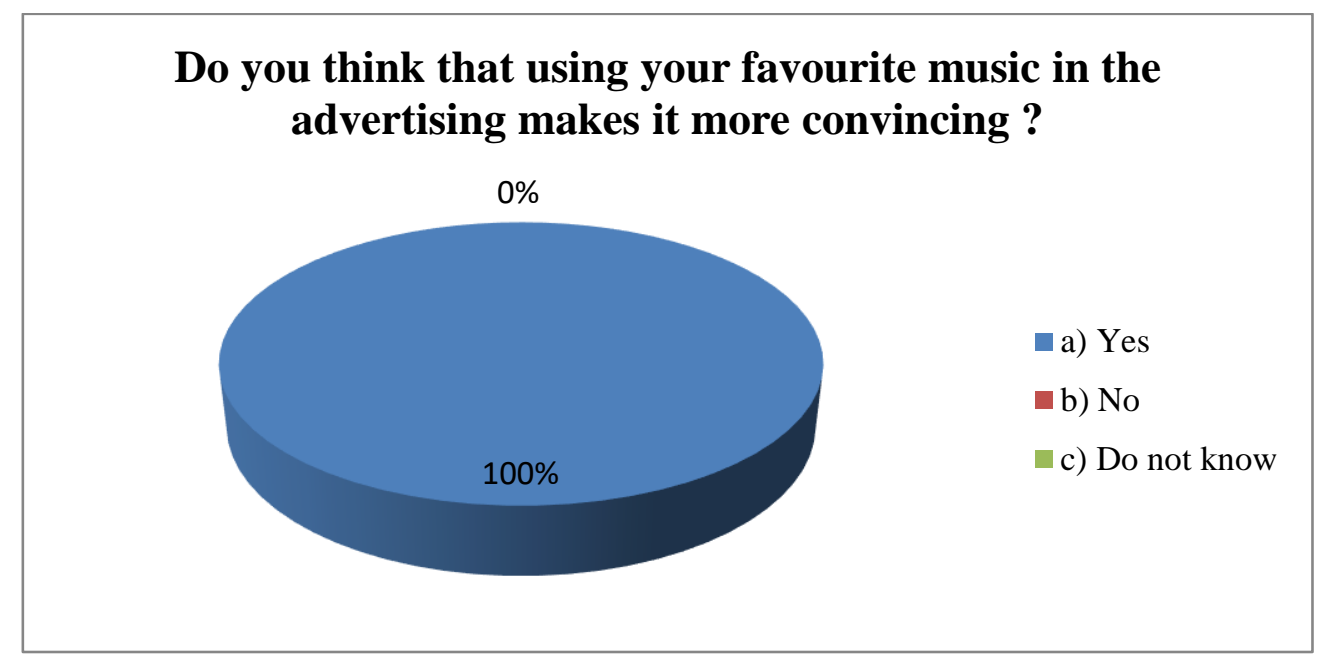

Source (authors 2020)

According to the surveyed consumers the role of music, which fits their musical preference, is very effective in convincing them of the product advertised on television.

Graph 9. Music in ads making products more memorable

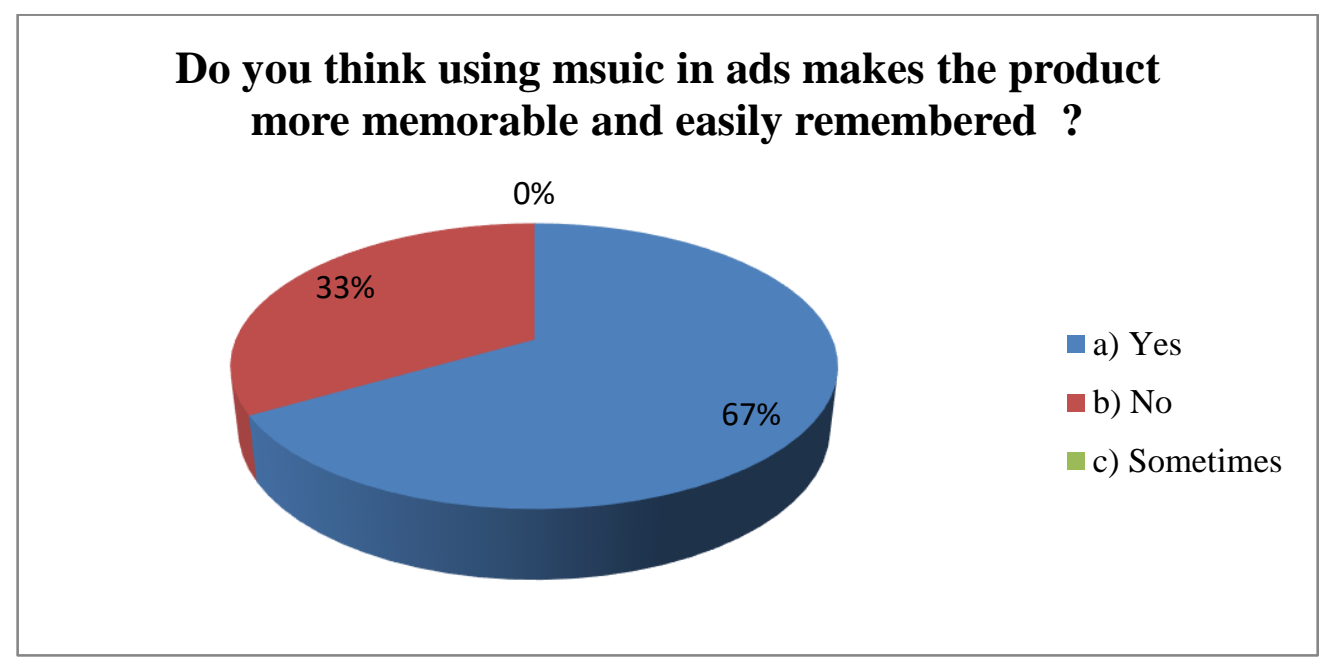

Source (authors 2020)

The replies to the fourth question of the survey were in favor of the musical line that follows advertisements, making it memorable and easily remembered as well. 
Graph 10. Establishing authority through music in advertising

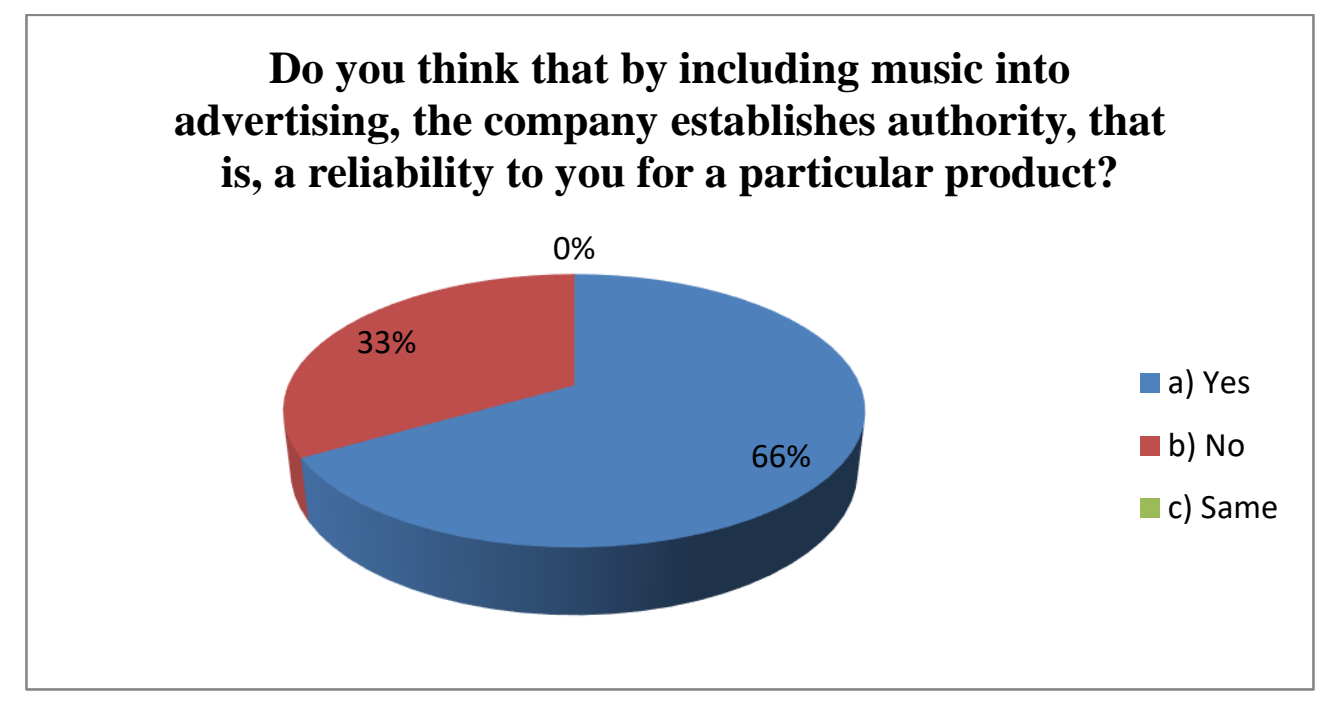

Source (authors 2020)

Also, according to $66 \%$ of customers, music in advertising affects the rise of company authority and increases the credibility of the quality of the advertised products.

\subsection{Findings Discussion}

After completing the questionnaire and analyzing the percentages of results, the accuracy of the hypotheses raised at the beginning of this paper wereassessed.

$\checkmark$ According to the results of the survey to managers, the music used in advertising has a strong influence on the effect of advertising purpose.

$\checkmark$ Even to consumers, the impact of advertising music lies in reinforcing the persuasion about product quality.and service.

$\checkmark$ Consumer survey responses indicate that advertising music is a crucial element in shaping the authority of commercial companies.

$\checkmark$ Also, according to the survey, the music in the ads is easily accessible to the consumer's ear.

$\checkmark$ The goal of increasing product sales is achieved through the proper selection and combination of music with advertisment text or words. So, selecting these elements while harmonizing with consumer music preferences.

\section{CONCLUSION AND RECOMMENDATIONS}

This research was conducted to a relatively considerable number of consumers and owners of companies, respectively managers, and the effect may not be general. But based on the findings, in every percentage, it is seen that music has an impact on almost all spheres of life, as in social, health and others, so does on advertising, and also make us understand that companies that in their commercials include music reach to bring the customer closer to the product, and earn the highest income in their sale. These ads are the result of a business or service that offers a valuable consideration, usually money, in exchange for the station that transmits their trading or mentions them on air in the broadcasts. 


\section{BIBLIOGRAPHY}

BERISHA, M.E. (1975), Historia e Muzikës I, Prishtinë.

ELAMZI, L. and BYTYQI, S., (2007), Drejtim Marketingu, Prishtinë.

ELAMZI, L. and BYTYQI, S., (2007), Drejtimi dhe strategjia ne marketing, Prishtinë.

Fakulteti i Filologjisë- UP, Prishtinë faqe 165.

HASANI, F. 2006/07.

http://drejtesia.blogspot.com/2007/06/ndikimi-i-reklams-n-zhvillimin-e.html

https://csml.som.ohio-state.edu/Huron/Publications/huron.advertising.text.html

JAKOVSKI, B. (1979), Marketing, Shkup.

KIGEN, U.J. and GRIN, M.C. (2014), Marketingu global, ArsLamina.

MULLINS, J.W. and JUNIOR, O.V., (2012), Menaxhimi i Marketingut, ArsLamina.

MusicalQuarterly (1989), Vol. 73, No. 4: 557-574.

REXHEPI, S., (2016), Seminari XXXV Ndërkombëtar për Gjuhën, Letërsinë dhe Kulturën shqiptare, Prishtinë. 